Volume 2, Nomor 2, Oktober 2021, hlm 52-60

JTTM: Jurnal Terapan Teknik Mesin

p ISSN 2721-5377| e ISSN 2721-7825

\title{
Analisis Kerusakan Bucket Elevator M-145 Dengan Metode Fishbone Diagram
}

\section{M145 Bucket Elevator Damage Analysis with Fishbone Diagram Method}

\author{
Arif Ardianto ${ }^{1 *}$, Wilarso ${ }^{2 *}$ \\ ${ }^{1,2^{*}}$ Program Studi Teknik Mesin, Sekolah Tinggi Teknologi Muhammadiyah Cileungsi \\ ${ }_{1,2^{*}} \mathrm{Jl}$. Anggrek No 25, Perum PTSC, Cileungsi, Bogor, Jawa Barat-Indonesia \\ *Koresponden Email: wilarso@sttmcileungsi.ac.id
}

Artikel dikirim: 19/08/202

Artikel direvisi: 24/10/2021

Artikel diterima: 26/10/2021

\begin{abstract}
Abstrak. Kerusakan mesin pada bucket elevator M-145 memberikan kontribusi terhadap downtime dibulan Januari 2021, sebanyak 605 menit atau 6.75 jam, mulai dari tanggal 17-20 Januari 2021 dengan total 17 kali downtime produksi. Tujuan dari penelitian ini menganalisis kerusakan elevator M145 untuk menentukan akar penyebab kerusakan dan dalam penelitian ini menggunakan metode fishbone diagram. Dari hasil penelitian yang dilakukan terjadi kerusakan elevator M-145 bahwa penyebab terjadinya overflow adalah karena terkelupasnya karet pelapis pulley atas pulley motor atas sehingga belt menjadi kendor dan menimbulkan gesekan pada belt conveyor, kekencangan belt conveyor yang jarang diperiksa, dari awal konstruksi bucket yang menyebabkan material tidak langsung terangkat ke atas melainkan teraduk terlebih dahulu dibawah sehingga menghambat laju bucket elevator. Dalam pencegahan kerusakan overflow pada mesin elevator M145 dengan cara memperbaiki atau mengganti pulley atas dengan pulley baru atau repair dengan memberikan pelapisan karet pulley yang baik, serta merubah arah lubang masuk elevator supaya bucket tidak lagi tertahan material bahan baku.
\end{abstract}

Kata Kunci: Bucket elevator, Overflow, fishbone diagram, Downtime, Elevator M145

Abstract. Machine failure on the M-145 bucket elevator contributed to downtime in January 2021, as much as 605 minutes or 6.75 hours, starting from January 17-20 2021 with a total of 17 production downtimes. The purpose of this study was to analyze the damage to the M145 elevator to determine the root cause of the damage and in this study used the fishbone diagram method. From the results of research conducted there was damage to the M145 elevator that the cause of the overflow was due to the peeling of the rubber coating on the top pulley of the upper motor pulley so that the belt became loose and caused friction on the conveyor belt, the tightness of the conveyor belt which was rarely checked, from the beginning of the construction of the bucket which caused the material to be indirect. lifted to the top but first stirred at the bottom so that it inhibits the speed of the bucket elevator. In preventing overflow damage on the M145 elevator machine by repairing or replacing the top pulley with a new pulley or repair by providing a good pulley rubber coating, as well as changing the direction of the elevator inlet so that the bucket is no longer stuck with raw materials.

Keywords: Bucket elevator, Overflow, Fishbone diagram, Downtime, Elevator M-145

\section{Pendahuluan}

Kegagalan kinerja mesin dalam sebuah proses produksi mengakibatkan terhentinya produksi yang tidak direncanakan dan mengakibatkan downtime[1][2][3]. Kerusakan komponen elevator M-145 menyebabkan mesin itu tidak dapat dipergunakan. Bucket elevator merupakan suatu bagian dari tahapan proses produksi dimana fungsinya memindahkan bahan baku[4][5]. Bilamana ditemukan kegagalan fungsi pada mesin elevator M-145 maka proses produksi bisa menimbulkan downtime yang berkepanjangan.

JTTM: Jurnal Terapan Teknik Mesin is licensed under a Creative Commons AttributionNonCommercial 4.0 International License. 
Kerusakan pada mesin elevator M-145 ditandai dengan peringatan overflow di monitor komputer, dimana motor dalam kondisi berputar sedangkan conveyor mengalami perlambatan dan tidak berputar sama sekali. Dimana bucket elevator M-145 mengalami kerusakan pada pulley pada motor, sehingga belt kendor dan menimbulkan gesekan pada belt conveyor[6][7]. Model konveyor sabuk dinamis yang dimodifikasi dengan tepat, dimungkinkan untuk secara cepat dan akurat menentukan dan memprediksi penyebab dan lokasi keausan penggerak konveyor[8].

Mulai bulan Januari 2021 telah terjadi downtime pada mesin elevator M-145 selama 605 menit atau 6,75 jam yang terjadi pada tanggal 17-20 Januari 2021 sebanyak 17 kali. Dalam menentukan akar penyebab kerusakan dari permasalahan mesin konveyor, di antaranya: a) Membahas kerusakan kerusakan yang terjadi dan frekuensi kerusakan yang terjadi pada bucket elevator M-145, b) Membahas pelaksanaan perawatan mesin yang dilakukan pada bucket elevator M-145, c) Pembahasan mengenai kerusakan-kerusakan yang berkaitan dengan penyebab putusnya belt elevator yang membutuhkan pengerjaan maintenance atau breakdown maintenance[9][10].

Penerapan realitas virtual diselidiki dan disajikan pada contoh analisis kegagalan untuk spesimen uji yang dipilih dari ban berjalan yang rusak[11]. Dalam penggunaan sensor magnetic, sensor hall dan giant magnetoresistance (GMR), sensor GMR dipergunakan untuk penginderaan perbedaan untuk mendeteksi kabel putus pada sistem elevator[8]. Tujuan dalam penelitian melakukan analisis kerusakan elevator M-145 terhadap kerusakan pada pulley motor yang mengakibatkan gesekan dengan belt conveyor.

\section{Metode Penelitian}

Alir penelitian kerusakan elevator M-145 ini dimulai dari identifikasi masalah dimana ditemukan pada gerakan motor berputar, namun elevator tidak berjalan. Penyusun fakta di lapangan berdasarkan pengecekan yang dilakukan terhadap kerusakan yang terjadi supaya mudah dalam menentukan akar penyebab.

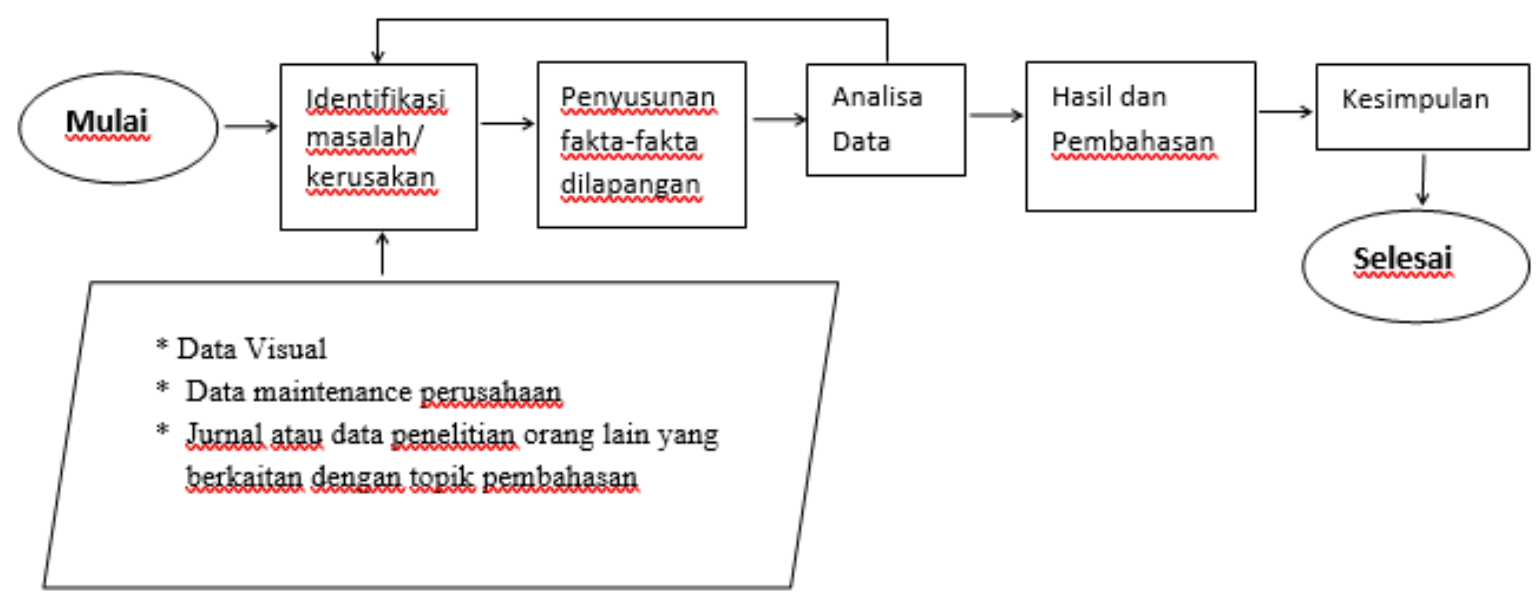

Gambar 1. Diagram alir penelitian 
Analisis Kerusakan Bucket Elevator M-145 Dengan Metode Fishbone Diagram

Analisa data sesuai dengan temuan yang didapat, kemudian di analisis komponen mana yang mempunyai kontribusi terhadap kerusakan tersebut, jika dalam analisis masih membutuhkan data, maka mulai dari awal kembali. Hasil dan pembahasan dalam penelitian ini adalah menentukan akar penyebab dari hasil analisis, kemudian menyimpulkan sesuai dengan tujuan dari penelitian, berdasarkan alir penelitian pada gambar 1 .

\section{Hasil Dan Pembahasan}

Kerusakan pada sebuah mesin industri terutama mesin bucket elevator antara lain dikarenakan rusaknya bearing, rotary couple, gearbox, bucket elevator yang patah/pecah, bahkan belt elevator putus sehingga diperlukan pengerjaan perbaikan membutuhkan waktu cukup lama[12]. Beberapa kejadian tersebut disebabkan oleh beberapa faktor antara lain, kondisi mesin yang sudah tidak normal (lifetime mesin), pemakaian mesin tidak sesuai dengan standar yang berlaku, perawatan mesin kurang baik, atau konstruksi mesin itu sendiri tidak sesuai dengan kebutuhan.

Dalam menentukan akar masalah dan solusi terbaik dari permasalahan mesin konveyor diperlukan identifikasi permasalahan supaya tercapai suatu kajian yang detail dan diharapkan mampu menentukan akar penyebab.

A. Identifikasi permasalahan dalam penelitian ini antara lain:

1) Mencari data-data kerusakan dan frekuensi kerusakan yang terjadi pada bucket elevator M145.

2) Mencari data pelaksanaan perawatan mesin yang dilakukan pada bucket elevator M-145.

3) Pembahasan mengenai kerusakan-kerusakan yang berkaitan dengan penyebab putusnya belt elevator serta pengerjaan maintenance atau breakdown maintenance yang sangat membutuhkan waktu.

Tabel 1. Data persentase permasalahan yang terjadi pada bulan Januari 2020

\begin{tabular}{lcccc}
\hline \hline \multicolumn{1}{c}{ Mesin } & $\begin{array}{c}\text { Jumlah } \\
\text { Masalah }\end{array}$ & $\begin{array}{c}\text { Akumulasi } \\
\text { Masalah }\end{array}$ & \% masalah & $\begin{array}{c}\text { \% Akumulasi } \\
\text { Masalah }\end{array}$ \\
\hline BPM 1 & 9 & 9 & $15 \%$ & $15 \%$ \\
CPM & 8 & 17 & $13 \%$ & $28 \%$ \\
GRINDING & 2 & 19 & $3 \%$ & $31 \%$ \\
INTAKE & 2 & 21 & $3 \%$ & $34 \%$ \\
KEMAS 3 & 2 & 23 & $3 \%$ & $38 \%$ \\
KEMAS 4 & 10 & 33 & $16 \%$ & $54 \%$ \\
MIXING & 28 & 61 & $46 \%$ & $100 \%$ \\
\hline \multicolumn{1}{c}{ JUMLAH } & $\mathbf{6 1}$ & & $\mathbf{1 0 0 \%}$ \\
\hline \hline
\end{tabular}




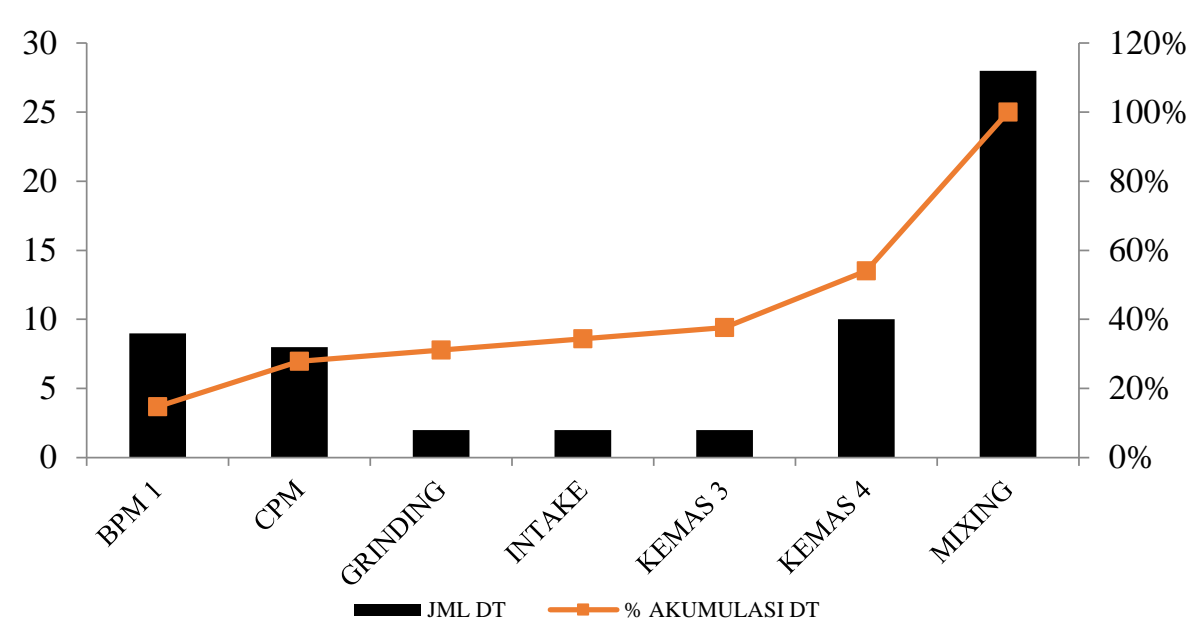

Gambar 2. Grafik akumulasi downtime produksi selama Januari 2020.

Data pada gambar 2 bahwa persentase kerusakan dan downtime produksi paling banyak terjadi pada line mixing, dimana bucket elevator M-145 merupakan bagian di dalam line produksi. Adapun kerusakan mesin elevator M-145 antara lain:

a) Overflow alarm yang disebabkan karena belt elevator kendor

b) Pecah dan patahnya bucket (suddenly) pada elevator akibat berbenturan dengan cover mesin atau benturan dengan material bahan itu sendiri karena beratnya material yang teraduk pada intake elevator.

c) Belt elevator tidak lurus dengan pulley.

d) Bearing rusak

e) Rubber couple rusak

f) Couple bergeser sehingga motor berputar sedangkan pulley elevator tidak berputar

g) Motor overload

h) Belt elevator putus.

Overflow alarm yang disebabkan karena belt elevator kendor, karena kejadian dimana motor listrik dan pulley dalam kondisi berputar sedangkan pulley bawah diam/tidak berputar. Hal ini berakibat rusaknya belt elevator dan juga rubber pulley atas (pulley motor). Sehingga lama kelamaan lapisan karet pulley menjadi tipis atau bahkan terkelupas dan juga bisa menyebabkan belt elevator menjadi lebih tipis atau bahkan dapat menyebabkan putusnya belt elevator[13]. Jika belt elevator gesekan dengan rubber pulley akan mengakibatkan panas dan menimbulkan kebakaran[14].

Pecah dan patahnya bucket secara tiba-tiba pada elevator akibat berbenturan dengan cover mesin ataupun karena benturan oleh material bahan itu sendiri karena beratnya material yang teraduk pada intake elevator. Pecah dan patahnya bucket elevator ini sendiri berdampak pada semakin berkurangnya kapasitas angkut pada tiap meter panjang elevator. Sehingga material lebih banyak 
Analisis Kerusakan Bucket Elevator M-145 Dengan Metode Fishbone Diagram

menumpuk di bagian intake bawah elevator yang mengakibatkan kerja bucket elevator, belt dan juga motor menjadi lebih berat.

a) Belt elevator tidak lurus dengan pulley (tidak center). Belt elevator yang tidak lurus mengakibatkan belt menjadi miring kesamping, bergesekan dengan body samping elevator, atau bahkan terlipat, dan juga bucket bertabrakan dengan body samping sehingga bucket penyok, patah ataupun pecah. Penanganannya yang dilakukan dengan cara setting belt sehingga kekencangan dan posisi belt bisa diperbaiki.

b) Bearing rusak, diakibatkan oleh umur bearing yang sudah lama, dan pelumasan bearing yang tidak terkontrol dengan baik dan kerusakan karena adanya kontaminasi material yang masuk atau mengkontaminasi bagian dalam bearing. Bila bearing sudah rusak otomatis menambah beban kerja bagi motor ataupun belt elevator.

c) Rubber couple rusak, Rusaknya rubber couple (kopling karet) pada sambungan kopling bisa mengakibatkan sambungan kopling menjadi lebih mudah bergeser atau meregang, sehingga mesin menjadi overflow (motor berputar sedangkan pulley atas tidak berputar)

d) Couple bergeser sehingga motor berputar sedangkan pulley elevator tidak berputar diakibatkan oleh kopling yang bergeser/meregang sehingga kopling beresiko rusak atau aus.

e) Motor overload, penyebab beban angkat elevator cukup berat disebabkan oleh tertumpuknya material bahan di input elevator, maupun output yang tersumbat.

f) Belt elevator putus, penyebab beban kerja belt yang terlalu tinggi (overload), umur pakai, belt yang kendur sehingga terjadi gesekan antara belt dengan pulley atas elevator, posisi belt miring sebelah mengakibatkan bucket tersangkut dengan body elevator.

\section{B. Data MTTR dan MTTF}

MTTR atau mean time between failure adalah rata rata kerusakan yang terjadi pada mesin atau kompunen mesin setelah selesai diperbaiki atau dengan kata lain merupakan jarak antara kerusakan satu dengan kerusakan yang lainya dalam satu mesin ataupun komponen mesin. Sedangkan Mine Time to Repair (MTTR) adalah rata rata waktu yang dibutuhkan untuk melakukan perbaikan pada sebuah mesin ataupun komponen mesin[15].

Tabel 2. Data MTTF dan MTTR yang didapatkan pada mesin M-145

\begin{tabular}{lcccccccc}
\hline & \multicolumn{10}{c}{ MESIN } \\
\hline \multicolumn{1}{c}{ Jan-21 } & Intake & Dosing & Grinding & Mixing & CPM & $\begin{array}{c}\text { BPM } \\
1\end{array}$ & $\begin{array}{c}\text { KEMAS } \\
3\end{array}$ & $\begin{array}{c}\text { KEMAS } \\
4\end{array}$ \\
\hline $\begin{array}{l}\text { MTBF } \\
\text { (days/kerusakan) }\end{array}$ & 15.00 & 30.00 & 15.00 & 1.07 & 3.75 & 3.33 & 15.00 & 3.00 \\
MTTR (min/kerusakan) & 52.50 & 0.00 & 55.00 & 25.11 & 21.81 & 38.74 & 33.75 & 18.25 \\
$\begin{array}{l}\text { Rework } \\
\text { Total Working }\end{array}$ & 15 & & & & & & & \\
$\begin{array}{l}\text { Breakdown } \\
\text { \% Work Efficiency }\end{array}$ & 61 & & & & & & & \\
\hline
\end{tabular}




\begin{tabular}{lll}
\hline Keterangan & Waktu & \\
\hline Hari Kerja & 30.00 & Hari \\
Jam kerja/hari & 24.0 & Jam \\
Total jam kerja/bulan & 720 & Jam \\
Istirahat & 0.0 & Jam \\
Preventive Maintenance & 11.5 & Jam \\
No Order & 0.0 & Jam \\
Planned Downtime STO & 12.7 & Jam \\
Planned Downtime Mesin & 4.3 & Jam \\
Jam Kerja Efektif & 691.5 & Jam \\
Breakdown & 28.7 & Jam \\
\% DT & $4.14 \%$ & \\
Total jam kerja Efektif & 691.5 & Jam \\
Total Breakdown & 28.7 & Jam \\
\hline \% DT & $4.14 \%$ & \\
\hline
\end{tabular}

Sehingga didapatkan grafik MTTR dan MTTF sesuai gambar 3.

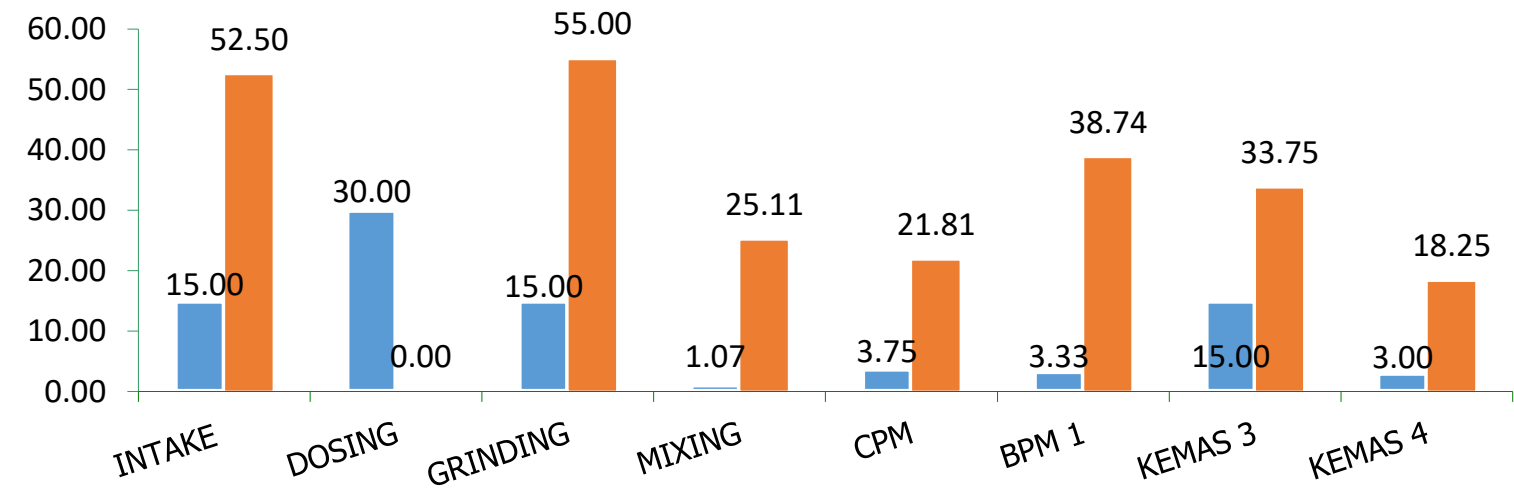

Gambar 3. Grafif MTTR dan MTTF

C. Analisa dengan menggunakan diagram tulang ikan

Dari data data yang kita dapatkan diatas maka didapat analisa dengan menggunakan diagram ishikawa /fishbone diagram yaitu sebagai berikut:

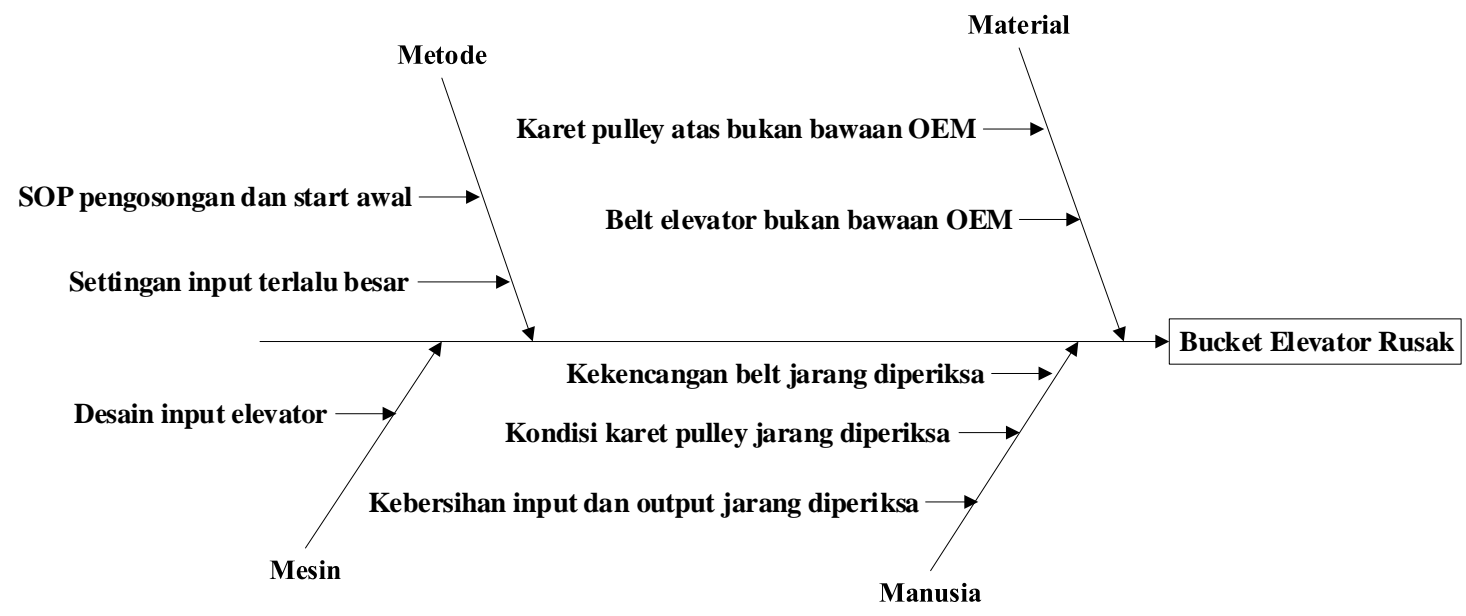

Gambar 4. Fishbone analysis. 
Analisis Kerusakan Bucket Elevator M-145 Dengan Metode Fishbone Diagram

\section{Penjelasan Diagram Ishikawa:}

A. Metode: Penyebab terjadinya belt putus pada kesalahan metode atau cara dalam pengoperasian alat adalah sebagai berikut:

1) SOP pengosongan dan mulai start awal yang kurang benar (elevator masih dalam keadaan terisi material) bisa menyebabkan beban motor, kopling, dan belt yang juga besar sehingga bisa menyebabkan resiko putusnya belt elevator.

2) Penambahan debit/setting input elevator yang terlalu besar sehingga beban bucket dan belt yang juga besar sehingga bisa menyebabkan resiko putusnya belt elevator.

B. Material komponen mesin

Ketersediaan sparepart yang harus impor dan juga mahalnya sparepart (OEM) biasanya menyebabkan penggunaan sparepart buatan lokal yang tersedia di dalam negeri, penggunaan sparepart tersebut biasanya tanpa mengetahui dimensi asli (presisi) dan juga material bahan yang digunakan oleh sparepart asli ataupun OEM sehingga menyebabkan reliability mesin yang berbeda dengan sparepart bawaan aslinya Penggunaan sparepart yang berbeda dengan sparepart OEM pada elevator M-145 adalah:

1) Penggunaan karet pulley atas elevator yang bukan original.

Sehingga ketahanan rekat karet (reliability) pulley menjadi berbeda. Karet pulley yang terlepas ini dapat menyebabkan gesekan dengan belt elevator sehingga belt elevator menjadi lebih tipis dan menjadi mudah putus bila terkena beban yang berlebih.

2) Penggunaan belt elevator yang bukan aslinya.

Penggunaan spare part lokal menyebabkan kekuatan elastisitas dan juga kekuatan gesek yang berbeda dengan sparepart belt asli, hal ini diketahui dengan tension (kekencangan) belt yang mudah kendur, sehingga gesekan dengan pulley atas menjadi tidak terhindarkan yang dapat menyebabkan putusnya belt elevator.

C. Manusia (Man Power)

Faktor manusia sebagai penggerak dan juga pelaksana program perawatan mesin menjadi sangat penting bagi reliability mesin itu sendiri. Adapun kesalahan yang disebabkan oleh faktor manusia di antaranya:

1) Kekencangan/tension belt yang jarang diperiksa secara berkala,

2) Kondisi karet pulley yang jarang diperiksa,

3) Kebersihan output dan Input yang jarang diperiksa.

D. Mesin

Faktor mesin mempunyai peran yang sangat penting dalam menentukan akar penyebab kerusakan, adapun faktor penyebab dari mesin diantaranya:

- Desain mesin yang menjadi faktor penyebab retak atau putusnya belt elevator adalah: karena letak posisi input yang bukan berada langsung pada arah naiknya putaran bucket 
elevator, melainkan material yang masuk pada input elevator harus diaduk terlebih dahulu di dalam boot elevator sehingga menyebabkan beban yang lebih besar pada bucket dan juga belt elevator.

\section{SIMPULAN}

Setelah dilakukannya penelitian dari kerusakan pada bagian pulley dan putusnya belt elevator M145 dengan menggunakan diagram tulang ikan maka, faktor kerusakan pada belt elevator tersebut disebabkan oleh manusia. Dimana proses pengecekan sebelum dan sesudah dioperasikan belum dilakukan terjadwal. Kemudian perawatan terhadap elevator belum dilakukan secara periodik, hal ini menyebabkan kerusakan yang berulang pada mesin tersebut. Langkah yang harus dilakukan adalah: a. Perlunya perbaikan dalam hal metode (Standar Operasional Prosedur) yang baik atau perlunya pelatihan terhadap operator dalam menerapkan SOP yang baik dan benar, b. Perlunya pengetahuan material dan juga penelitian reliability mesin terhadap material sparepart yang dipakai terutama pada material yang bukan premium parts, c. Perlunya penerapan sistem maintenance yang baik atau bila perlu diadakannya pelatihan-pelatihan terhadap aplikasi dari sistem maintenance yang baik terhadap petugas di lapangan maupun para pembuat keputusan (stakeholder), d. Perlunya dilakukan perubahan desain mesin/ posisi intake agar material yang masuk bisa langsung dibawa ke atas tanpa harus diaduk terlebih dahulu di boot elevator.

\section{REFERENSI}

[1] D. Dewanti, D. F., \& Pujotomo, “Analisis Penyebab Cacat Produk Kain Dengan Menggunakan Metode Failure Mode And Effect Analysis (FMEA)," Progr. Stud. Tek. Ind. Fak. Tek. Univ. Diponegoro, 2018.

[2] M. Sayuti and S. D. Saifannur, "Penentuan Jadwal Perawatan Bus Pada Cv. Nuri Jaya," Malikussaleh J. Mech. Sci. Technol., vol. 2, no. 2, 2014.

[3] I. N. Putri, "Analisis Risiko Kegagalan Produk Mempengaruhi Kualitas Pelayanan Menggunakan House Of Risk Dan Supply Chain Operations Reference," J. Optimasi Tek. Ind., vol. 2, no. 1, 2020, doi: 10.30998/joti.v2i1.4049.

[4] L. L. Schumacher et al., "Feed batch sequencing to decrease the risk of porcine epidemic diarrhea virus (PEDV) cross-contamination during feed manufacturing," J. Anim. Sci., vol. 96, no. 11, 2018, doi: 10.1093/jas/sky320.

[5] P. Kroupa, "The outer quality loss during grain post-harvest treatment and handling," Res. Agric. Eng., vol. 49, no. No. 3, 2018, doi: 10.17221/4958-rae.

[6] G. A. Taher, Y. Howlader, A. Rabbi, and F. A. Touqir, "Automation of Material Handling with Bucket Elevator and Belt Conveyor," Int. J. Sci. Res. Publ., vol. 4, no. 3, 2014.

[7] S. T. Jadhav, "Design and Fabrication of Bucket Elevator," Int. J. Res. Appl. Sci. Eng. Technol., vol. 9, no. VI, 2021, doi: 10.22214/ijraset.2021.35625. 
Analisis Kerusakan Bucket Elevator M-145 Dengan Metode Fishbone Diagram

[8] H. M. Lei and G. Y. Tian, "Broken wire detection in coated steel belts using the magnetic flux leakage method," Insight Non-Destructive Test. Cond. Monit., vol. 55, no. 3, 2013, doi: 10.1784/insi.2012.55.3.126.

[9] K. Nemtinov, A. Eruslanov, and Y. Nemtinova, "Rationale construction of individual elements of technological complex," in MATEC Web of Conferences, 2018, vol. 224, doi: 10.1051/matecconf/201822402036.

[10] Gangga Putra Mahardika, Agus Tjahjono, and Sumardi, "IDENTIFIKASI PENYEBAB RUSAKNYA HEAVY LIQUID CHAMBER PADA LO PURIFIER MITSUBISHI SJ25T DI MV. JINGU DENGAN METODE FTA," Din. Bahari, vol. 7, no. 2, 2017, doi: 10.46484/db.v7i2.43.

[11] G. Fedorko, "Application possibilities of virtual reality in failure analysis of conveyor belts," Eng. Fail. Anal., vol. 128, 2021, doi: 10.1016/j.engfailanal.2021.105615.

[12] H. Iizuka, "Failure mechanism of drive belts," Toraibarojisuto/Journal Japanese Soc. Tribol., vol. 63, no. 8, 2018, doi: 10.18914/tribologist.63.08_539.

[13] M. L. P. Tonatto, M. M. C. Forte, and S. C. Amico, "Compressive-tensile fatigue behavior of cords/rubber composites," Polym. Test., vol. 61, 2017, doi: 10.1016/j.polymertesting.2017.05.024.

[14] J. B. Vorderbrueggen, "Imperial sugar refinery combustible dust explosion investigation," Process Saf. Prog., vol. 30, no. 1, 2011, doi: 10.1002/prs.10445.

[15] S. Franklin, Redefining Maintenance-Delivering Reliability. 2008. 